REVIEW

\title{
Superheroes in autoimmune warfare: Biologic therapies in current South African practice
}

G Tarr, ${ }^{1}$ MB BCh, FCP (SA), Cert Rheum (SA), MMed (Int Med); B Hodkinson, ${ }^{2}$ MB BCh, FCP (SA), Cert Rheum (SA), PhD;

H Reuter, ${ }^{1,3}$ MB ChB, FCP (SA), MMed (Int), FRCP (Edin), PhD

${ }^{1}$ Winelands Rheumatology Research Centre, Stellenbosch, South Africa

${ }^{2}$ Department of Medicine, Groote Schuur Hospital and University of Cape Town, and Division of Rheumatology, Chris Hani Baragwanath Academic Hospital, Faculty of Health Sciences, University of the Witwatersrand, Johannesburg, South Africa

${ }^{3}$ Division of Rheumatology, Department of Medicine, Faculty of Medicine and Health Sciences, Stellenbosch University, Cape Town, South Africa

Corresponding author: B Hodkinson (drbridget@gmail.com)

Biologic drugs targeting immune cells or cytokines underlying systemic inflammation have dramatically improved outcomes in patients with rheumatological and autoimmune diseases. Nine biologic drugs are currently available in South Africa (SA) - all showing good efficacy and safety profiles. Their high cost and potential adverse events preclude them from being used as first-line agents. They are therefore indicated for severe disease refractory to standard therapies, and their use must be initiated by a specialist. The most important adverse effect of this class of drugs is infection and, in SA, tuberculosis is of particular concern. As new targets in the immune system are identified, new biologics will be developed. The current challenges are to optimise standard care for all patients with autoimmune diseases, and to offer the appropriate biologic to patients with refractory disease.

S Afr Med J 2014;104(11):787-791. DOI:10.7196/SAMJ.8947

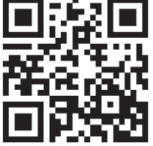

Everyone who reads comics knows that winning is about recognising the villains, choosing the superhero with precisely the right 'superpowers' to overcome the bad guy, and sitting back to enjoy the action. The last two decades have been exciting times in the battle against autoimmune diseases. The villains have been elucidated owing to a growing understanding of the immunological mechanisms underlying the co-ordinated interaction between $\mathrm{T}$ and $\mathrm{B}$ cells and pro-inflammatory cytokines responsible for systemic inflammation, followed by the development of targeted biologic drugs with 'superpowers' against specific immune cells or cytokines. These biologic therapies have dramatically improved outcomes in patients with a range of autoimmune conditions, including rheumatoid arthritis (RA), ankylosing spondylitis (AS), psoriasis and psoriatic arthritis (PsA), and inflammatory bowel disease (IBD), as well as systemic inflammatory diseases such as lupus erythematosus (SLE) and the vasculitides.

The biologic disease-modifying anti-rheumatic drugs (DMARDs) are classified according to their target. There are currently eight registered biologic drugs in South Africa (SA), of which four are tumour necrosis factor alpha inhibitors (TNFi) and four are non-
TNFi, including ustekinumab, which is currently registered for the treatment of psoriasis but not for the arthritides (Table 1). Their structure is specified by the abbreviation at the end of their name: '-cept' = fusion of a receptor to the Fc part of human IgG1; '-mab' = monoclonal antibody; '-ximab' = chimeric monoclonal antibody; and '-umab' = humanised monoclonal antibody.

Many patients respond to the conventional synthetic DMARDs. Because of the high cost and potential adverse events, biologic drugs are reserved for patients with severe disease who fail to respond to standard treatments. In SA, the use of biologic therapies needs to be initiated by a specialist, who follows the guidelines published online by the relevant specialist associations, including the South African Gastroenterology Society (www.SAGES.co.za), the South African Rheumatology Association (www.SARAA.co.za), ${ }^{[1]}$ and the Dermatology Society of South Africa (www.DERMA.co.za). ${ }^{[2]}$

\section{Rheumatoid arthritis}

Biologic therapies have made an enormous impact on severe RA by modulating disease activity and retarding radiographic damage, thus preventing disability. Patients with active disease despite synthetic DMARDs over at least six months can be considered candidates 
Table 1. Biologic drugs in South Africa

\begin{tabular}{|c|c|c|c|c|c|}
\hline Biologic drug & $\begin{array}{l}\text { Mechanism of } \\
\text { action }\end{array}$ & $\begin{array}{l}\text { Route of } \\
\text { administration }\end{array}$ & $\begin{array}{l}\text { Registered } \\
\text { indications }\end{array}$ & $\begin{array}{l}\text { Off-label } \\
\text { indications }\end{array}$ & $\begin{array}{l}\text { Major adverse } \\
\text { effects }\end{array}$ \\
\hline $\begin{array}{l}\text { Infliximab } \\
\text { (Revellex) }\end{array}$ & $\begin{array}{l}\text { Mouse/human } \\
\text { chimeric mab } \\
\text { against TNF- } \alpha\end{array}$ & IV every 8 weeks & $\begin{array}{l}\text { RA, AS, PS, PSA, } \\
\text { CD, UC, PaedCD, } \\
\text { PaedUC }\end{array}$ & \multirow{5}{*}{$\begin{array}{l}\text { JIA, } \\
\text { SJIA, } \\
\text { uveitis, } \\
\text { Takayasu } \\
\text { arteritis, GCA, } \\
\text { pyoderma } \\
\text { gangrenosum, } \\
\text { sarcoidosis }\end{array}$} & \multirow{5}{*}{$\begin{array}{l}\text { Serious infections, } \\
\text { including: } \\
\text { tuberculosis, } \\
\text { hepatitis B } \\
\text { reactivation, } \\
\text { demyelinating } \\
\text { disorders }\end{array}$} \\
\hline $\begin{array}{l}\text { Etanercept } \\
\text { (Enbrel) }\end{array}$ & $\begin{array}{l}\text { Soluble TNF- } a \\
\text { receptor fusion } \\
\text { protein }\end{array}$ & SC weekly & RA, AS, PS, PSA, JIA & & \\
\hline $\begin{array}{l}\text { Adalimumab } \\
\text { (Humira) }\end{array}$ & Mab against TNF- $\alpha$ & SC every other week & $\begin{array}{l}\text { RA, AS, axial } \\
\text { spondylo- } \\
\text { arthropathies, PS, } \\
\text { PSA,CD, UC, JIA, } \\
\text { PaedCD }\end{array}$ & & \\
\hline $\begin{array}{l}\text { Golimumab } \\
\text { (Simponi) }\end{array}$ & $\begin{array}{l}\text { Human mab against } \\
\text { TNF- } \alpha\end{array}$ & SC monthly & RA, AS, PSA, UC ${ }^{*}$ & & \\
\hline Certolizumab pegol ${ }^{+}$ & $\begin{array}{l}\text { Human mab against } \\
\text { TNF- } \alpha\end{array}$ & SC monthly & $\begin{array}{l}\mathrm{RA},{ }^{*} \mathrm{CD},{ }^{*} \mathrm{AS},{ }^{*} \\
\mathrm{PSA}^{*}\end{array}$ & & \\
\hline $\begin{array}{l}\text { Abatacept } \\
\text { (Orencia) }\end{array}$ & $\begin{array}{l}\text { Receptor fusion } \\
\text { protein inhibiting } \\
\text { T-cell co-stimulation }\end{array}$ & $\begin{array}{l}\text { IV monthly or SC } \\
\text { weekly }\end{array}$ & RA, JIA & SLE & \\
\hline $\begin{array}{l}\text { Rituximab } \\
\text { (Mabthera) }\end{array}$ & $\begin{array}{l}\text { Mouse/human } \\
\text { chimeric mab } \\
\text { against CD } 20^{+} \mathrm{B} \\
\text { cells }\end{array}$ & IV 6-monthly & $\begin{array}{l}\text { RA, ANCA- } \\
\text { associated vasculitis, } \\
\text { haematological } \\
\text { malignancies, NHL, } \\
\text { CLL }\end{array}$ & $\begin{array}{l}\text { SLE, } \\
\text { pemphigus } \\
\text { vulgaris, } \\
\text { inflammatory } \\
\text { myopathies }\end{array}$ & $\begin{array}{l}\text { Serious infections: } \\
\text { hepatitis B } \\
\text { reactivation, } \\
\text { progressive } \\
\text { multifocal } \\
\text { leukoencephalopathy }\end{array}$ \\
\hline $\begin{array}{l}\text { Tocilizumab } \\
\text { (Actemra) }\end{array}$ & $\begin{array}{l}\text { Humanised IL-6 } \\
\text { receptor antibody }\end{array}$ & IV monthly & RA, SJIA, JIA* & $\begin{array}{l}\text { Castleman's, } \\
\text { CD, relapsing } \\
\text { polychondritis, } \\
\text { SLE, SScL, } \\
\text { PMR, RS3PE }\end{array}$ & $\begin{array}{l}\text { Infection: } \\
\text { neutropenia, } \\
\text { transaminitis, } \\
\text { dyslipidaemia, } \\
\text { GI perforation }\end{array}$ \\
\hline $\begin{array}{l}\text { Ustekinumab } \\
\text { (Stelara) }\end{array}$ & $\begin{array}{l}\text { IL- } 12 / 23 \text { monoclonal } \\
\text { antibody }\end{array}$ & & $\mathrm{PS}, \mathrm{PSA},{ }^{*} \mathrm{CD}^{*}$ & UC & Serious infections \\
\hline
\end{tabular}

for biologic therapy. Seven of the currently available biologics are registered for first-line use in RA, and systemic reviews suggest that these biologics have similar efficacies. ${ }^{[3,4]}$ The choice of drug depends on the side-effect profile, disease characteristics, patient preferences for route of administration, and cost. Because of the high risk of tuberculosis (TB) in SA, particularly associated with TNFi, biologic drugs with an alternative mode of action may be the most appropriate choice as first-line therapy ${ }^{[5]}$ In addition, certain disease features may guide the choice of drug, e.g. rheumatoid factor-negative patients are less likely to respond to rituximab, and those with pronounced systemic symptoms (such as anaemia of chronic disorders, high C-reactive protein and fatigue) are likely to have a good response to 
tocilizumab. Methotrexate or leflunomide should be co-prescribed with biologics, except in the case of tocilizumab, where there is good evidence for monotherapy. The Janus kinase (JAK) inhibitor tofacitinib is a new synthetic DMARD with equivalent efficacy to the biologic agents used in the treatment of RA, but it is not yet registered in SA.

\section{Ankylosing spondylitis}

The TNFi drugs dramatically improve the symptoms and reduce the radiographic progression of AS. Randomised controlled studies of all four TNFi have shown good efficacy in early and advanced disease. Younger age, shorter disease duration, high inflammatory markers, human leukocyte antigen (HLA) B27 positivity and minimal baseline functional disability are associated with better outcomes. ${ }^{[6]}$ Loss of response to TNFi over time is well documented in AS, probably related to TNFi antibody production. In these patients, switching to an alternative TNFi may be efficacious. Other biologics (rituximab, abatacept and tocilizumab) have shown only limited success in AS. In future, secukinumab (an interleukin (IL)17A inhibitor) may be useful.

\section{Psoriasis}

Persistent severe plaque psoriasis resistant to standard therapies is an indication for TNFi therapy. ${ }^{[2]}$ Similarly, PsA (including peripheral arthritis, axial disease, enthesitis and dactylitis) has shown a rapid and significant response to TNFi with inhibition of radiographic disease progression. ${ }^{[7]}$ More recently, ustekinumab, an IL-12/IL-23 monoclonal antibody, has been shown to be effective in psoriasis and PsA, but is currently only registered for plaque psoriasis. In addition, drugs inhibiting IL-17 seem promising, particularly for skin disease and enthesitis. ${ }^{[8]}$

\section{Inflammatory bowel disease}

In Crohn's disease, monoclonal antibodies that inhibit TNF (but not TNF receptor blockers) are beneficial in steroid-refractory, steroid-dependent, or complex fistulising disease. This induction therapy needs to be continued for at least 12 months in patients who show a response. ${ }^{[9]}$ The TNFi is usually prescribed together with an immunosuppressive agent, with evidence particularly favouring azathioprine. ${ }^{[10]}$ Similarly, TNFi are also effective for treatmentrefractory, moderate, or severely active ulcerative colitis. Patients with IBD-associated axial or peripheral arthritis refractory to sulfasalazine may also benefit from TNFi. Ustekinumab has been shown to be useful in TNF-resistant Crohn's disease. ${ }^{[1]]}$ Abatacept and natalizumab (an integrin receptor antagonist) may also be effective in Crohn's disease and trials are ongoing.

\section{Juvenile idiopathic arthritis}

Biologic drugs have greatly improved outcomes in refractory polyarticular and oligoarticular juvenile idiopathic arthritis (JIA), and TNFi have been the most widely studied biologics in these diseases. A recent systematic review demonstrated that etanercept, adalimumab and abatacept were equally efficacious. ${ }^{[12]}$ Refractory systemic JIA has shown good response to tocilizumab, and to IL-1 inhibitors including anakinra, canakinumab and rilonocept and encouraging study results have been reported with tofacitinib. The IL-1 inhibitors and tofacitinib are not yet licensed in SA.

\section{Systemic lupus erythematosus}

Despite initial optimism that biologic drugs would lead to new therapeutic options, most clinical trials in SLE have missed their primary endpoints. ${ }^{[13]}$ Belimumab inhibits B-cell activation factor, which is also known as B-lymphocyte stimulator. It has been shown to reduce flares and antibody titres in mild to moderate SLE (excluding renal or central nervous system (CNS) involvement) and is the only biologic registered in the USA for use in SLE. Rituximab (for haematological, renal and CNS involvement), abatacept (for arthritis), and TNFi (for skin and joint disease) have been successfully used off-label.

\section{ANCA-associated vasculitis, uveitis and Behçet's syndrome}

Rituximab is one of the few biologics to have been studied in antineutrophilic cytoplasmic antibody (ANCA)-associated vasculitis, and has been shown to be non-inferior to cyclophosphamide for induction therapy ${ }^{[14,15]}$

Although no randomised controlled trials have been published, observational studies have shown benefit in cyclophosphamideresistant disease. In refractory Behçet's disease, both TNFi infliximab and adalimumab were effective, also for severe ocular inflammation, whereas etanercept was less effective for ocular or gastrointestinal manifestations. ${ }^{[16]}$

\section{IgG4 sclerosing-related disease}

Immunoglobulin (Ig) G4-related disease is a rare, recently characterised, immune-mediated fibrosing disorder, with varying clinical manifestations depending on the specific organ system involved. Mainstay treatment is corticosteroids, but immunosuppressants may be added in relapsing patients or as steroid-sparing agents. Rituximab may be useful in refractory patients. ${ }^{[17]}$

\section{Adverse effects of biologics}

While the efficacy of biologic drugs has been clearly established, the risk of adverse effects has been uncertain, and has only recently been clarified by Cochrane meta-analysis and by literature review. ${ }^{[18,19]}$ Table 1 summarises the major adverse effects of various biologics available in SA. A great concern with all biologic treatments, with the exception of abatacept, is the increased risk of community-acquired and opportunistic infections. Of particular importance in SA is the risk of TB infection or reactivation, which is only partially addressed 
by screening for latent TB infection and isoniazid prophylaxis. In studies conducted in countries with a low TB prevalence, the risk of TB seems highest among patients receiving monoclonal TNFi during their first year of treatment and rises as high as a 56 -fold increased incidence compared with the general population. ${ }^{[20-22]}$ Although initially of concern, malignancies do not seem to increase in patients using biologics except for a possible increase in melanoma associated with TNFi. ${ }^{[23]}$

\section{Switching and withdrawing biologic therapy}

Despite impressive results in the majority of patients, response to a specific biologic drug is unpredictable and up to one-third of patients with an autoimmune disease requiring biologic therapy have a poor response or lose their response. These patients may respond to switching to another biologic drug. The search for biomarkers to allow optimal selection of biologic drugs is ongoing.

Given the costs and potential adverse effects, withdrawal or reduction of biologic therapy is a goal of many patients and physicians. In RA, AS and PsA, this may be possible in a subset of patients who have achieved long-term remission, particularly in those with early disease, and studies are ongoing. ${ }^{[24]}$ In the case of IBD, withdrawal of TNFi therapy in patients who have been in clinical remission $\geq 12$ months appears safe in the majority of patients.

\section{Vaccination}

Because of the increased risk of serious infections in patients using biologics, vaccination is an important preventive strategy. ${ }^{[25,26]}$ Current recommendations are that vaccines, particularly influenza and pneumococcal vaccines, be given prior to biologic therapy where possible, and that live vaccines (including measles, mumps, rubella, live attenuated influenza, varicella zoster, yellow fever, Ty21a oral typhoid, bacillus Calmette-Guérin (BCG), and rotavirus vaccines) are contraindicated. ${ }^{[27]}$

\section{Cost of biologic drugs}

One of the major problems restricting biologic use in SA is their cost, ranging between R110 000 and R160 000 annually. Offset against this cost is the benefit of early disease control, thus reducing the impact of the disease on functional capabilities and work productivity. A recent French study demonstrated that even though early biologic therapy in RA was costly, it resulted in lower health-associated costs (including physician consultations, investigations and hospitalisation) over a 4 -year period owing to better disease control. ${ }^{[28]}$ Long-term studies in $\mathrm{SA}$ are needed to evaluate the cost of biologics against the economic burdens of poorly controlled disease.

Healthcare providers and patient groups in SA need to lobby for wider access to biologics for patients who require them, in both the private and state sectors. This might entail pharmaceutical companies offering drugs at reduced prices, greater flexibility by medical schemes for patients with limited cover, and the use of biosimilar drugs.

\section{Biologic registries}

Biologic registries are a major source of efficacy and safety data, and a registry of rheumatology patients who are on biologic therapy has been in operation in SA since 2008. A recent paper describes the SA experience of TNFi therapy in RA, showing results similar to those seen elsewhere in the world. ${ }^{[29]}$ Further clinical research, using the epidemiological data from the SA registry, will help to develop evidence-based treatment guidelines with regard to TB risks and latent TB detection, strategies to monitor patients on biologics, and long-term cost-effectiveness of treatment.

\section{Conclusion}

Ben Parker, uncle to Peter Parker aka Spiderman, remarked 'With great power comes great responsibility'. So it is with biologic drugs. As our knowledge of the underlying mechanisms of autoimmune diseases expands, we can expect more targeted therapies to be developed. Our growing experience with biologics and their adverse events will include development of clinical and laboratory biomarkers to allow selection of optimal therapy for each patient. The current and future challenges in SA are to optimise the standard care for patients with autoimmune diseases, with careful selection of patients with severe refractory disease and provision of the appropriate biologic drugs.

\section{References}

1. Hodkinson B, Van Duuren E, Pettipher C, Kalla A, South African Rheumatism and Arthritis Association. South African recommendations for the management of rheumatoid arthritis: An algorithm for the standard of care in 2013. S Afr Med J 2013;103:576-585. [http://dx.doi.org/10.7196/samj.7047]

2. Raboobee N, Aboobaker J, Jordaan HF, et al. Guideline on the management of psoriasis in South Africa. S Afr Med J 2010;100:257-282.

3. Singh JA, Christensen R, Wells GA, et al. Biologics for rheumatoid arthritis: An overview of Cochrane reviews. Cochrane Database Syst Rev 2009;(4):CD007848.

4. Nam JL, Winthrop KL, van Vollenhoven RF, et al. Current evidence for the management of rheumatoid arthritis with biological disease-modifying antirheumatic drugs: A systematic literature review informing the EULAR recommendations for the management of RA. Ann Rheum Dis 2010;69(6):976986. [http://dx.doi.org/10.1136/ard.2009.126573]

5. Tikly M, Hodkinson B, Dheda K. Biologic therapy for rheumatoid arthritis in developing countries - a place for non-TNF inhibitors as first-line treatment? Rheumatology [Epub ahead of print 31 March 2014]. [http://dx.doi.org/10.1093/rheumatology/keu040]

6. Vastesaeger N, van der Heijde D, Inman RD, et al. Predicting the outcome of ankylosing spondylitis therapy. Ann Rheum Dis 2011;70(6):973-981. [http://dx.doi.org/10.1136/ard.2010.147744]

7. Thorlund K, Druyts E, Avina-Zubieta JA, Mills EJ. Anti-tumor necrosis factor (TNF) drugs for the treatment of psoriatic arthritis: An indirect comparison meta-analysis. Biologics: Targets \& Therapy 2012;6:417-427.

8. Huynh D, Kavanaugh A. Psoriatic arthritis: Current therapy and future approaches. Rheumatology [Epub ahead of print 14 August 2014]. [http://dx.doi.org/10.1093/rheumatology/keu237]

9. D'Haens GR, Panaccione R, Higgins PD, et al. The London Position Statement of the World Congress of Gastroenterology on Biological Therapy for IBD with the European Crohn's and Colitis Organization: When to start, when to stop, which drug to choose, and how to predict response? Am J Gastroentero 2011;106(2):199-212. [http://dx.doi.org/10.1038/aj. 2010.392]

10. Lakatos PL. Is there a benefit from the concomitant use of immunosuppression with anti-TNF in Crohn's disease; heads or tails? Rev Recent Clin Trials 2009;4(3):152-158. [http://dx.doi. org/10.2174/157488709789957664]

11. Sandborn WJ, Feagan BG, Fedorak RN, et al. A randomized trial of Ustekinumab, a human interleukin-12/23 monoclonal antibody, in patients with moderate-to-severe Crohn's disease. Gastroenterology 2008;135(4):1130-1141. [http://dx.doi.org/10.1053/j.gastro.2008.07.014] 
12. Otten MH, Anink J, Spronk S, van Suijlekom-Smit LW. Efficacy of biological agents in juvenile idiopathic arthritis: A systematic review using indirect comparisons. Ann Rheum Dis 2013-72(11):1806-1812 [http://dx.doi.org/10.1136/annrheumdis-2012-201991]

13. Gatto M, Kiss E, Naparstek Y, Doria A. In-/off-label use of biologic therapy in systemic lupus erythematosus. BMC Med 2014;12:30. [http://dx.doi.org/10.1186/1741-7015-12-30]
erter

14. Stone JH, Merkel PA, Spiera R, et al. Rituximab versus cyclophosphamide for ANCA-associated vasculitis. N Engl J Med 2010;363(3):221-232. [http://dx.doi.org/10.1056/NEJMoa0909905]

15. Jones RB, Tervaert JW, Hauser T, et al. Rituximab versus cyclophosphamide in ANCA-associated renal vasculitis. N Engl J Med 2010;363(3):211-220. [http://dx.doi.org/10.1056/NEJMoa0909169]

16. Bawazeer A, Raffa LH, Nizamuddin SH. Clinical experience with adalimumab in the treatment of ocular Behçet disease. Ocul Immunol Inflamm 2010;18(3):226-332. [http://dx.doi.org/10.3109/09273948.2010.483314]

17. Khosroshahi A, Carruthers MN, Deshpande V, Unizony S, Bloch DB, Stone JH. Rituximab for the (1) treatment of $\mathrm{IgG4}$-related disease: Lessons from $10 \mathrm{C}$

18. Singh JA, Wells GA, Christensen R, et al. Adverse effects of biologics: A network meta-analysis and Cochrane overview. Cochrane Database Syst Rev 2011;(2):CD008794.

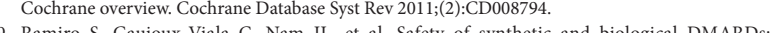
. Ramiro S, Gatoux systematic literature review informing the 2013 update of he EULAR recommendations for org/10.1136/annrheumdis-2013-204575]

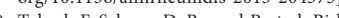

. Tubach monoclonal antibody therapy than with soluble tumor necrosis factor receptor therapy: The threeyear prospective French Research Axed on Tolerance of
21. Dixon WG, Hyrich KL, Watson KD, et al. Drug-specific risk of tuberculosis in patients with rheumatoid arthritis treated with anti-TNF therapy: Results from the British Society for Rheumatology Biologic Register (BSRBR). Ann Rheum Dis 2010;69(3):522-528. [http://dx.doi.org/10.1136/ard.2009.118935]

22. Lee SK, Kim SY, Kim EY, et al. Mycobacterial infections in patients treated with tumor necrosis factor antagonists in South Korea. Lung 2013;191(5):565-571. [http://dx.doi.org/10.1007/s00408-013-9481-5]

23. Raaschou P, Simard JF, Holmqvist M, Askling J, Group AS. Rheumatoid arthritis, anti-tumour necrosis factor therapy, and risk of malignant melanoma: Nationwide population based prospective cohort study from Sweden. BMJ 2013;346:f1939.

24. Kadar G, Balazs E, Soos B, et al. Disease activity after the discontinuation of biological therapy in inflammator rheumatic diseases. Clin Rheumatol 2014;33(3):329-333. [http:///dx.doi.org/10.1007/s10067-014-2508-3]

25. Doran MF, Crowson CS, Pond GR, O'Fallon WM, Gabriel SE. Frequency of infection in patients with rheumatoid arthritis compared with controls: A population-based study. Arthritis Rheum 2002;46(9):2287-2293. [http://dx.doi.org/10.1002/art.10524]

26. Bongartz T, Sutton AJ, Sweeting MJ, Buchan I, Matteson EL, Montori V. Anti-TNF antibody therapy in

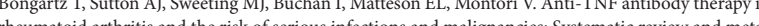
6. 2285. [http://dx.doi.org/10.1001/jama.295.19.2275]

27. Ferreira I, Isenberg D. Vaccines and biologics. Ann Rheum Dis 2014;73(8):1446-1454. [http://dx.doi. org/10.1136/annrheumdis-2014-205246]

28. Chevreul K, Haour G, Lucier S, et al. Evolution of direct costs in the first years of rheumatoid arthritis: Impact of early versus late biologic initiation - an economic analysis based on the ESPOIR cohort. PloS One 2014:9(5):e97077. [http://dx.doi.org/10.1371/journal.pone.0097077]

29. Pettipher C, Rudolph R, Musenge E, Tikly M. A prospective study of anti-tumor necrosis factor therapy in South African rheumatoid arthritis patients. Int J Rheum Dis 12 February 2014. [Epub ahead of print] 